\title{
The Effect of Artificial Neural Network Architecture on Surface Roughness Parameter Pre- diction Capability when Turning Inconel 718
}

\author{
Marek Vrabel'1, Ildikó Maňková1, Miroslav Pal'o ${ }^{1}$, Radek Lattner ${ }^{2}$ \\ ${ }^{1}$ Faculty of Mechanical Engineering, Technical University of Kosice, Masiarska 74, 04001 Kosice, Slovakia. E-mail: \\ marek.vrabel@tuke.sk, ildiko.mankova@tuke.sk,miroslav.palo@tuke.sk \\ ${ }^{2}$ Faculty of Production Technology and Management, J. E. Purkyne University in Usti nad Labem. Pasteurova 3334/7, \\ 40001 Usti nad Labem. Czech Republic. E-mail: lattnerr@fvtm.ujep.cz
}

This paper investigates the influence of Artificial Neural Network (ANN) architectures on its prediction capability when machining nickel based super alloy. The ANN was employed to determine surface roughness parameter Ra through cutting conditions, tool wear and process monitoring indices such a cutting force components. The ANN structure was optimized by methods like a reduction of input vector parameters, dimensions of input data pattern, combined reduction and modification of hidden layers. Calculated and experimentally measured values were compared for each optimized ANN model. The work concludes that optimization of ANN has significant influence on prediction capability and accuracy for the task proposed.

Keywords: Artificial Neural Network, Optimization, Turning, Surface Roughness, Nickel Based Alloy

\section{Acknowledgement}

This work was supported by the bilateral project APVV SK-SRB-2013-0037 "Implementation of the artificial intelligence into optimisation of the selected advanced removal processes" as well as the project VEGA 1/0434/15 "Research on process dependent interface when milling with small diameter of end mill cutters"

\section{References}

[1] PONTES, F. J., DE PAIVA A. P., BALESTRASSI, P. P., FERREIRA, J. R., DA SILVA, M. B. F P. (2012). Optimization of radial basis function neural network employed for predictionof surface roughness in hard turning process using Taguchi's orthogonal arrays. In: Expert Systems with Application, Vol. 39, pp. 7776 - 7787.

[2] GARCÍA-PLAZA, E., NÚŇEZ, P. J., SALGADO, D. R., CAMBERO, I., HERRERA OLIVENZA, J. M., GARCÍA SANZ-CALCEDO, J. (2013). Surface finishmonitoring in taper turning CNC using artificial neural network and multiple regression methods. In: Procedia Engineering, The Manufacturing Engineering Society International Conference - MESIC 2013, Vol. 63, pp. $21-25$.

[3] SEGRETO, T., SIMEONE, A., TETI, R. (2013). Multiple sensor monitoring in nickel alloy turning for tool wear assessment via sensor fusion. In: Procedia CIRP, Conference on Intelligent Computation in Manufacturing Engineering, Vol. 12, pp. $237-261$.

[4] SIMEONE, A., SEGRETO T., TETI R. (2013). Residual stress condition monitoring via sensor fusion in turning of Inconel 718. In: Procedia CIRP, Conference on Intelligent Computation in Manufacturing Engineering, Vol. 12 , pp. $67-72$.

[5] JAWAHIR, I. S., BRINKSMEIER, E., M'SAOUBI, R. M, ASPINWALL, D. K., OUTEIRO, J. C., MEYER, D., UMBRELLO, D., JAYAL, A. D. (2011). Surface integrity in material removal processes: Recent advances, In: CIRP Annals - Manufacturing Technology, Vol. 60, pp. $603-626$.

[6] MAŇKOVÁ, I., VRABEL, M., KOVAČ, P (2013). Artificial neural network application for surface roughness prediction when drilling nickel based alloy. In: Manufacturing Technology, Vol. 13, No. 2, pp. 193 - 199.

[7] NOVAK, M., NAPRSTKOVA, N. (2015). Grinding of the Alloy INCONEL 718 and Final Roughness of the Surface and Material Share. In: Manufacturing Technology, Vol. 15, No. 6, pp. 1015 - 1023.

[8] BELAN, J., KUCHARIKOVÁ, L., TILLOVÁ, E., UHRÍČIK, M. (2015). The Overview of Intermetallic Phases Presented in Nickel Base Superalloys after Precipitation Hardening. In: Manufacturing Technology, Vol. 15, No. 4, pp. $509-515$. 